Review

\title{
The fate of P2Y-related orphan receptors: GPR80/99 and GPR91 are receptors of dicarboxylic acids
}

\author{
Nathalie Suarez Gonzalez ${ }^{1,3}$, Didier Communi ${ }^{1}$, Sébastien Hannedouche ${ }^{3} \&$ Jean-Marie Boeynaems ${ }^{1,2}$ \\ ${ }^{1}$ Institute of Interdisciplinary Research, School of Medicine, Free University of Brussels, Brussels, Belgium; ${ }^{2}$ Laboratory \\ of Medical Chemistry, Erasme Hospital, Free University of Brussels, Brussels, Belgium; ${ }^{3}$ Euroscreen Inc., Brussels, \\ Belgium
}

Received 30 August 2004; accepted in revised form 15 October 2004

Key words: $\alpha$-ketoglutarate, G-protein coupled, nucleotide, orphan, P2Y, receptor, succinate

\begin{abstract}
Several orphan G protein-coupled receptors are structurally close to the family of P2Y nucleotide receptors: GPR80/99 and GPR91 are close to P2Y $\mathrm{Y}_{1 / 2 / 4 / 6 / 11}$ receptors, whereas GPR87, H963 and GPR34 are close to P2Y $12 / 13 / 14$. Over the years, several laboratories have attempted without success to identify the ligands of those receptors. In early 2004 , two papers have been published: One claiming that GPR80/99 is an AMP receptor, called P2 $\mathrm{Y}_{15}$, and the other one showing that GPR80/99 is a receptor for $\alpha$-ketoglutarate, while GPR91 is a succinate receptor. The accompanying paper by Qi et al. entirely supports that GPR80/99 is an $\alpha$-ketoglutarate receptor and not an AMP receptor. The closeness of dicarboxylic acid and P2Y nucleotide receptors might be linked to the negative charges of both types of ligands and the involvement of conserved Arg residues in their neutralization.
\end{abstract}

\section{Introduction}

One of the most comprehensive and recent analysis of the human genome concluded that the repertoire of $\mathrm{G}$ proteincoupled receptors for endogenous ligands consists of 367 human genes and 392 murine genes [1]. At that time, 187 among the 367 human receptors remained orphan, but the ligands of a few of them have now been identified. Of those 187 orphan receptors, 51 were considered to belong to families with known ligands, on the basis of phylogenetic analysis. The P2Y family of nucleotide receptors is subdivided into two structurally distant subfamilies [2]. A first group includes the $\mathrm{P} 2 \mathrm{Y}_{1}, \mathrm{P} 2 \mathrm{Y}_{2}, \mathrm{P} 2 \mathrm{Y}_{4}, \mathrm{P} 2 \mathrm{Y}_{6}$ and $\mathrm{P} 2 \mathrm{Y}_{11}$ receptors. $\mathrm{P} 2 \mathrm{Y}_{12}, \mathrm{P}_{2} \mathrm{Y}_{13}$ and $\mathrm{P} 2 \mathrm{Y}_{14}$ belong to a second group. Vassilatis et al. included three orphan receptors in the P2Y family: GPR80 (also called GPR99) and GPR91 in the first group, and GPR87 in the second one. Other orphan receptors (H963 and GPR34) are also close to the last group (Figure 1). A previous phylogenetic analysis had reached the same conclusions [3]. The inclusion of GPR80/99 and GRP91 in the P2Y family was further supported by the presence in their sequence of structural motifs conserved among genuine $\mathrm{P} 2 \mathrm{Y}$ receptors [2]. Indeed, all $\mathrm{P} 2 \mathrm{Y}$ receptors belonging to the first group $\left(\mathrm{P} 2 \mathrm{Y}_{1 / 2 / 4 / 6 / 11}\right)$ have one histidine and one arginine/lysine residues in transmembrane domain (TM) 6 and one

Correspondence to: Dr Jean-Marie Boeynaems, Chimie Médicale, Erasme Hospital, 808, Route de Lennik, 1070 Brussels, Belgium. Tel: +32-25553922; Fax: +32-2-5556655; E-mail: jmboeyna@ulb.ac.be arginine residue in TM7 (Figure 2). In the case of the $\mathrm{P} 2 \mathrm{Y}_{2}$ receptor, mutagenesis experiments have demonstrated that these residues play a crucial role in receptor activation by ATP/UTP [17].

\section{History of GPR91 and GPR80/99}

The first description of human GPR91 dates back to 1995 [4]. At the time, it was called $\mathrm{P} 2_{\mathrm{U} 2}$ because it was closest to the then $\mathrm{P} 2 \mathrm{U}-$ now $\mathrm{P} 2 \mathrm{Y}_{2}$ - receptor $(31 \%$ amino acid identity). Northern blot revealed an abundant expression of mRNA in the kidney, but expression was also detected in megakaryocytic cell lines, mainly DAMI cells. It was reported in a patent application that Xenopus oocytes expressing $\mathrm{P} 2{ }_{\mathrm{U} 2}$ mRNA became responsive to nucleotides with the following rank order of potency: UTP $>$ UDP $>$ $\mathrm{ADP}>\mathrm{ATP}$ [5]. The same human receptor and its murine ortholog were rediscovered using an expressed sequence tag data mining strategy and called GPR91 [6]. Again, a high expression of the human mRNA was found in the kidney, while the murine one was also present in the liver. The human GPR91 gene was located on the chromosome 3q24-3q25, where it belongs to a cluster including also the $\mathrm{P} 2 \mathrm{Y}_{1}, \mathrm{P} 2 \mathrm{Y}_{12}, \mathrm{P} 2 \mathrm{Y}_{13}$ and $\mathrm{P} 2 \mathrm{Y}_{14}$ genes $[2,6]$.

In 2000, Communi et al. discovered a new P2Y-like sequence by RT-PCR homology cloning based on the sequences of $\mathrm{P} 2 \mathrm{Y}_{1}$ and $\mathrm{P} 2 \mathrm{Y}_{11}$ receptors (Communi et al., unpublished data). That receptor was stably expressed in $1321 \mathrm{~N} 1$ and CHO-K1 cells. Although initial data obtained 


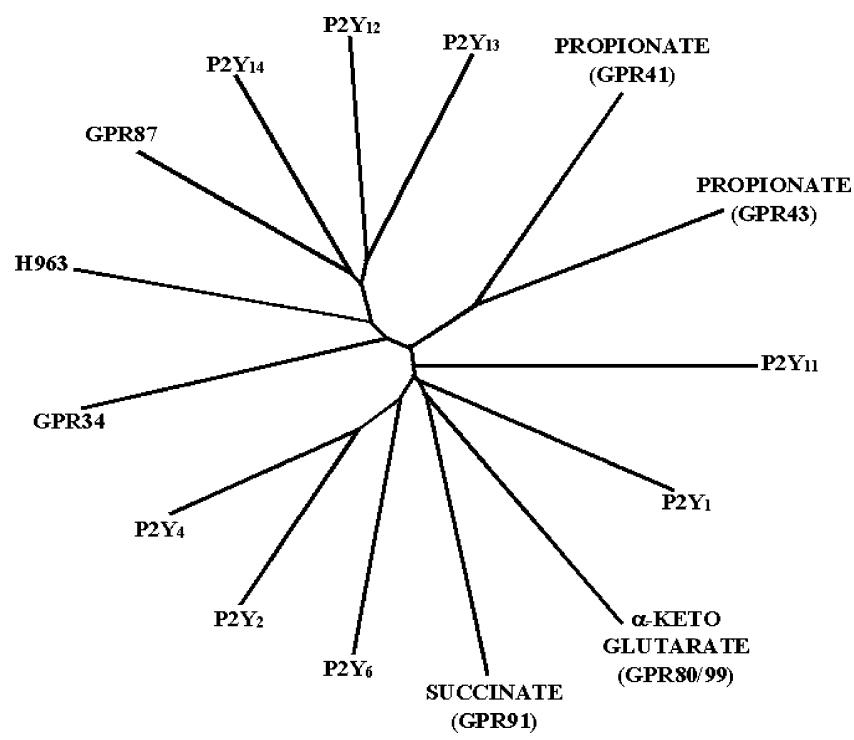

Figure 1. Phylogenetic tree illustrating the relatedness of the two groups of $\mathrm{P} 2 \mathrm{Y}$ receptors, dicarboxylic acid receptors, receptors for short-chain monocarboxylic acids and remaining orphan $\mathrm{P} 2 \mathrm{Y}$-like receptors. The following receptors are included in the tree: $\mathrm{P} 2 \mathrm{Y}$ receptors, group I: $\mathrm{P} 2 \mathrm{Y}_{1}$, $\mathrm{P}_{2} \mathrm{Y}_{2}, \mathrm{P}_{2} \mathrm{Y}_{4}, \mathrm{P}_{2} \mathrm{Y}_{6}$ and $\mathrm{P} 2 \mathrm{Y}_{11}$; $\mathrm{P} 2 \mathrm{Y}$ receptors, group II: $\mathrm{P} 2 \mathrm{Y}_{12}, \mathrm{P}_{2} \mathrm{Y}_{13}$ and P2 $\mathrm{Y}_{14}$; Dicarboxylic acid receptors: succinate (GPR91) and $\alpha$-ketoglutarate (GPR80/99); Monocarboxylic acid (propionate) receptors: GPR41 and GPR43; Orphan P2Y-like receptors: GPR87, H963 and GPR34. Alignment was performed using ClustalX algorithm and the dendrogram was constructed using the TreeView algorithm.

with the use of the microphysiometer suggested that the new receptor could be an ADP receptor, the ADP response was not confirmed by inositol phosphates or cAMP measurements and was apparently due to the degradation of ADP into adenosine (Communi et al., unpublished data). Northern blots were negative for several human organs but gave a strong positive signal for the human thyroid gland (Communi et al., unpublished data). Using genomic sequences database search and PCR, Lee et al. reported the existence of the same sequence under the name GPR80 and noticed its relatedness to $\mathrm{P} 2 \mathrm{Y}$ receptors [7]. Northern blots were negative for various brain regions. The same sequence was also described later by Wittenberger et al. [8], who called it GPR99 and mapped the gene on chromosome 13q32.2. Following expression in oocytes, these authors failed to detect any response to a range of nucleotides. Northern blotting revealed a signal in kidney and a weaker one in placenta.

\section{Identification of GPR81 and GPR80/GPR99 ligands}

In March 2004, Inbe et al. [9] reported that in HEK293 cell clones stably expressing HA-tagged GPR80/99, AMP induced $\mathrm{Ca}^{2+}$ mobilization and cAMP generation, while it had almost no effect on untransfected cells. These responses were inhibited by theophylline and other xanthines. Furthermore they detected a binding of $\left[{ }^{32} \mathrm{P}\right]$ AMP to HEK293 cells expressing GPR80/99. Quantitative RT-PCR revealed expression in the kidney, as mentioned earlier, but also in the trachea and mast cells. The authors speculated that GPR80/99, that they renamed $\mathrm{P}_{2} \mathrm{Y}_{15}$, could be the target responsible for the bronchodilatory action of theophylline.

Another paper identifying the ligands of GPR80/99 and GPR91 appeared in May 2004 [10]. To deorphanize GPR91, these authors started from the observation that its mRNA is strikingly abundant in one organ: The kidney. Following RP-HPLC purification of a kidney extract, one fraction was able to activate GPR91 expressed in $\mathrm{CHO}$ cells and was found to contain succinate. In HEK293 cells stably expressing GPR91, succinate $(10-100 \mu \mathrm{M})$ increased inositol phosphate formation (with partial inhibition by pertussis toxin) and inhibited the formation of cAMP, thus indicating dual coupling to $G_{q / 11}$ and $G_{i}$. By analogy GPR80/99 was found to be responsive to another

\section{Group I:}

\begin{tabular}{|c|c|c|c|c|c|c|c|c|c|}
\hline$h P 2 Y_{1}$ & . L LQ & $\underline{\mathrm{R}} \mathrm{F} I F \underline{\mathrm{H}}$ & VN. . & $\ldots I P F$ & $\underline{\text { H}}$ VMK & TMN . - & - ATY & $\underline{Q V T R}$ & GLA . . \\
\hline $\mathrm{hP} 2 \mathrm{Y}_{2}$ & $\ldots L V$ & RFLFY & TN . . & . LPF & $\underline{\mathrm{H}} \mathrm{VT} \underline{\mathrm{R}}$ & TLY.. & - MAY & $\underline{\text { KVTR }}$ & PLA. . \\
\hline$h \mathrm{P} 2 \mathrm{Y}_{4}$ & $\ldots \mathrm{FV}$ & RFLFY & WWN . - & $\ldots \quad V P F$ & HITR & TIY . & . VVY & KVTR & PLA. . \\
\hline $\mathrm{hP} 2 \mathrm{Y}_{6}$ & $\therefore L \mathrm{LV}$ & RFLF $Y$ & AN . - & . LPF & HITK & TAY . - & - AAY & KGTR & PFA. . \\
\hline$h P 2 Y_{11}$ & $\therefore L E$ & RFLFT & $\mathrm{CN}$. & $\ldots \quad V P Y$ & HIMR & VLN . - & . VGY & QVMR & GLM. . \\
\hline GPR 99 & $\ldots F I$ & RFSFH & FN.. & . LPF & $\mathrm{HILR}$ & VIR. . & $\ldots E A Y$ & IvsR & PLA. . \\
\hline GPR 91 & $\ldots \mathrm{SN}$ & $\underline{\mathrm{R}} Y \mathrm{~L} \underline{\mathrm{H}}$ & AN. . & . TPY & $\underline{\text { HVMR }}$ & NVR. . & - .SFY & IVTR & PLA. . \\
\hline
\end{tabular}

Group II:

\begin{tabular}{|c|c|c|}
\hline $\mathrm{hP} 2 \mathrm{Y}_{12}$ & $\ldots \quad \mathrm{VT}$ & SVIFY \\
\hline $\mathrm{hP} 2 \mathrm{Y}_{13}$ & $\ldots \mathrm{FS}$ & SVIFY \\
\hline $\mathrm{hP} 2 \mathrm{Y}_{14}$ & . v vs & AVLFY \\
\hline PR 87 & & SVLFY \\
\hline 963 & & ACLIY \\
\hline PR34 & $\mathrm{vv}$ & GTLFY \\
\hline
\end{tabular}

TM3

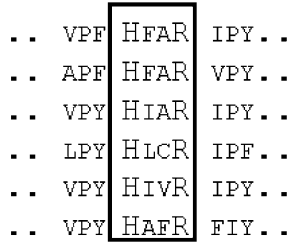

TM6

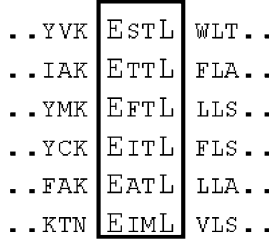

TM7

Figure 2. Role of conserved positively charged residues in the activation of P2Y and dicarboxylic acid receptors by their respective ligands. Conserved residues among P2Y and/or dicarboxylic acids receptors are shown in a higher size font. The residues that have been mutated in the studies of Erb et al. [17], Jiang et al. [14] and He et al. [10] are underlined. Those residues that are crucial in the activation of those receptors are in bold. 


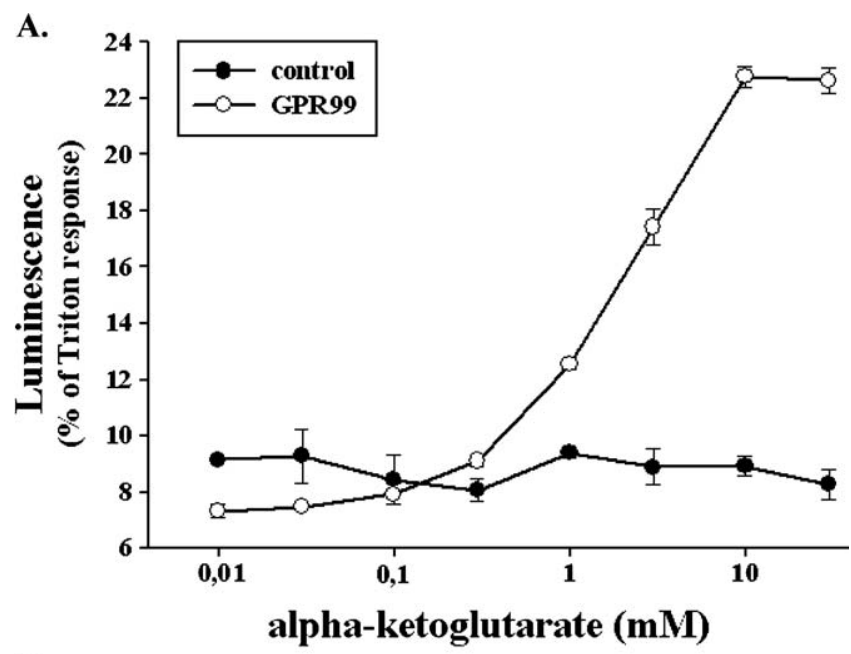

B.

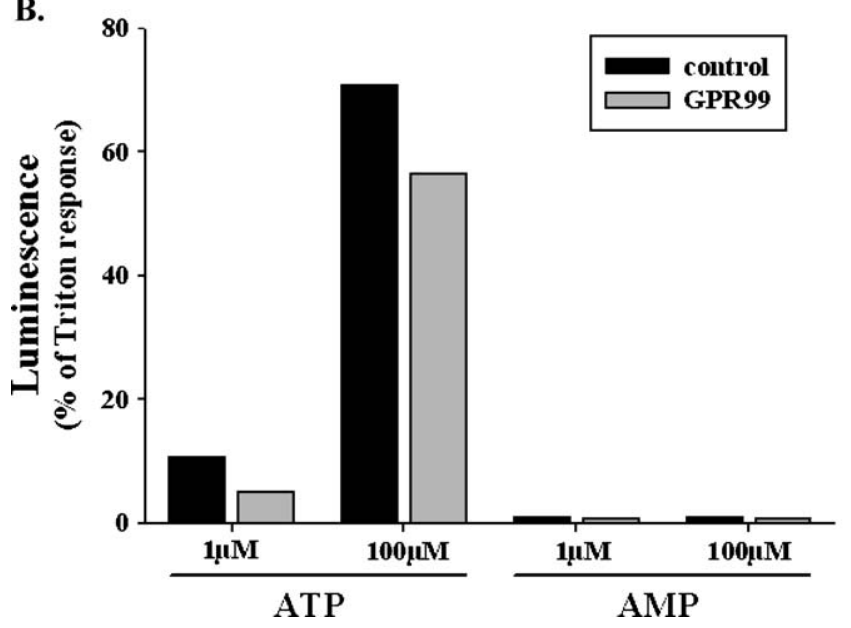

Figure 3. Comparison of the responses to $\alpha$-ketoglutarate (A) and AMP (B) in an aequorin-based functional assay using CHO-K1 cells coexpressing human GPR80/99, apo-aequorin and $\mathrm{G \alpha}_{16}$. The plasmid was transfected into CHO-K1 cells expressing $\mathrm{G}_{16}$ and a mitochondria-targeted form of apoaequorin. Clonal cell lines were established, and functional responses were analyzed using a bioassay based on the luminescence of aequorin, in the presence of $5 \mu \mathrm{M}$ coelenterazine $\mathrm{H}$, as a result of intracellular calcium release, as described previously $[15,16]$. Briefly, cells $(25,000$ cells in $50 \mu \mathrm{l})$ were added to $50-\mu 1$ samples in 96 -well plates, and the luminescence was recorded for $30 \mathrm{~s}$ (Berthold luminometer). Maximal response was evaluated following cell lysis by Triton X-100. The ATP response is due to endogenous $\mathrm{P}_{2} \mathrm{Y}_{2}$ receptors.

citric acid cycle intermediate: $\alpha$-ketoglutarate. In contrast with GPR91, it coupled exclusively to $G_{\mathrm{q} / 11}$. Almost 30 years ago, extracellular succinate was shown to induce renin release from the kidney in vitro: He et al. [10] showed that i.v. succinate stimulated the release of renin in mice and that this effect is abolished in GPR91-deficient mice.

The demonstration that GPR91 is a succinate receptor and GPR80/GPR99 a receptor for $\alpha$-ketoglutarate is very strong [10]. In contrast, the report that GPR80/GPR99 would be the $\mathrm{P} 2 \mathrm{Y}_{15}$ receptor of AMP suffers from one major pitfall: The pharmacological properties of GPR80/ GPR99 were evaluated in a single expression system, the HEK293 cells [9]. It is indeed known that HEK293 cells expressed endogenous $A_{2 B}$ receptors coupled to both $G_{q}$ and $\mathrm{G}_{\mathrm{s}}$ [11]. As expected, Inbe et al. [9] found an endogenous response to adenosine, though not AMP, in untransfected
HEK293 cells. There was apparently no difference in AMP degradation into adenosine between the plain HEK293 cells and the clone expressing GPR80/GPR99. However, the level of $A_{2 B}$ receptor expression might vary between different clones of HEK293 cells. This explanation is consistent with the results presented in the accompanying paper by Qi et al. [18] who failed to detect any response to adenosine or AMP in either COS-7, CHO-K1 or HEK293 cells expressing HA-tagged GPR80/99, whereas in the same cells these authors found a striking response to $\alpha$-ketoglutarate. We made similar observations in a CHO-K1 cell line co-expressing $\mathrm{G \alpha}_{16}$ and apoaequorin (Figure 3).

\section{Discussion}

For several years it was believed that GPR80/99 and GPR91 were potential P2Y receptors. This belief was supported by sequence homology, conservation of characteristic positively charged residues in TM6 and TM7, and even chromosomal location in case of GPR91. However He et al. [10] have now provided a clear-cut demonstration that GPR91 is a succinate receptor and GPR80/99 a receptor for $\alpha$-ketoglutarate. The recent report by Inbe et al. [9] that GPR80/99 would be a receptor for AMP, called $\mathrm{P} 2 \mathrm{Y}_{15}$, represents a source of confusion. The accompanying paper by Qi et al. [18], as well data from other groups (Communi et al., unpublished data; [8]), demonstrate that GPR80/99 is not an AMP receptor and should not be associated with the name $\mathrm{P}_{2} \mathrm{Y}_{15}$. One might wonder if the structural closeness of dicarboxylic acid and $\mathrm{P} 2 \mathrm{Y}$ nucleotide receptors is merely fortuitous. Succinate is very close chemically to propionate and butyrate, which have their own receptors [12, 13]: GPR41 and GPR43. Interestingly, the succinate and $\alpha$-ketoglutarate receptors are closer to the first group of $\mathrm{P} 2 \mathrm{Y}$ receptors than to these receptors for short-chain monocarboxylic acids (Figure 1). Furthermore, three of the positively charged residues characteristic of the P2Y family and the importance of which has been established by mutagenesis [14, 17], an Arg residue in TM3 (Arg99), an Arg residue in TM6 (Arg252) and another Arg residue in TM7 (Arg281), appear to be involved in the binding of the dicarboxylic acids, since their mutation in GPR91 abolished the responsiveness to succinate [10]. This suggests that some of the residues involved in neutralizing the phosphate negative charges of nucleotides play the same role towards the carboxylate negative charges of dicarboxylic acids (Figure 2). In conclusion, GPR80/99 and GPR91 are dicarboxylic acid receptors and not $\mathrm{P} 2 \mathrm{Y}$ receptors, and the name $\mathrm{P} 2 \mathrm{Y}_{15}$ should not be used to designate GPR80/99, which is a receptor for $\alpha$-ketoglutarate.

\section{References}

1. Vassilatis DK, Hohmann JG, Zeng H et al. The G protein-coupled receptor repertoires of human and mouse. Proc Natl Acad Sci USA 2003; 100: 4903-8. 
2. Abbracchio MP, Boeynaems JM, Barnard EA et al. Characterization of the UDP-glucose receptor (re-named here the $\mathrm{P}_{2} \mathrm{Y}_{14}$ receptor) adds diversity to the $\mathrm{P} 2 \mathrm{Y}$ receptor family. Trends Pharmacol Sci 2003; 24: 52-5.

3. Joost P, Methner A. Phylogenetic analysis of 277 human G-proteincoupled receptors as a tool for the prediction of orphan receptor ligands. Genome Biol 2002; 3: RESEARCH0063.

4. Conley P, Vincent D, Tai A et al. Cloning of a novel purinoceptor from a human megacaryocytic cell line. Blood 1995; 86: $316 \mathrm{a}$.

5. Conley PB, Jantzen HM. Methods of screening for compounds that interact with human $\mathrm{P} 2_{\mathrm{U} 2}$ purinergic receptor. US Patent 6063582, 2000.

6. Wittenberger T, Schaller HC, Hellebrand S. An expressed sequence tag (EST) data mining strategy succeeding in the discovery of new G-protein coupled receptors. J Mol Biol 2001; 307: 799-813.

7. Lee DK, Nguyen T, Lynch KR et al. Discovery and mapping of ten novel G protein-coupled receptor genes. Gene 2001; 257: 83-91.

8. Wittenberger T, Hellebrand S, Munck A et al. GPR99, a new G protein-coupled receptor with homology to a new subgroup of nucleotide receptors. BMC Genomics 2002; 3: 17.

9. Inbe $\mathrm{H}$, Watanabe $\mathrm{S}$, Miyawaki $\mathrm{M}$ et al. Identification and characterization of a cell-surface receptor, $\mathrm{P} 2 \mathrm{Y}_{15}$, for AMP and adenosine. J Biol Chem 2004; 279: 19790-9.

10. He W, Miao FJ, Lin DC et al. Citric acid cycle intermediates as ligands for orphan G-protein-coupled receptors. Nature 2004; 429 : 188-93.

11. Linden $\mathrm{J}$, Thai $\mathrm{T}$, Figler $\mathrm{H}$ et al. Characterization of human $\mathrm{A}_{2 \mathrm{~B}}$ adenosine receptors: Radioligand binding, Western blotting, and coupling to $\mathrm{G}_{\mathrm{q}}$ in human embryonic kidney 293 cells and HMC-1 mast cells. Mol Pharmacol 1999; 56: 705-13.

12. Brown AJ, Goldsworthy SM, Barnes AA et al. The orphan G protein-coupled receptors GPR41 and GPR43 are activated by propionate and other short chain carboxylic acids. J Biol Chem 2003; 278: 11312-9.

13. Le Poul E, Loison C, Struyf S et al. Functional characterization of human receptors for short chain fatty acids and their role in polymorphonuclear cell activation. J Biol Chem 2003; 278: 25481-9.

14. Jiang Q, Guo D, Lee BX et al. A mutational analysis of residues essential for ligand recognition at the human $\mathrm{P}_{2} \mathrm{Y}_{1}$ receptor. $\mathrm{Mol}$ Pharmacol 1997; 52: 499-507.

15. Stables J, Green A, Marshall F et al. A bioluminescent assay for agonist activity at potentially any G-protein-coupled receptor. Anal Biochem 1997; 252: 115-26.

16. Blanpain C, Doranz BJ, Vakili J et al. Multiple charged and aromatic residues in CCR5 amino-terminal domain are involved in high affinity binding of both chemokines and HIV-1 Env protein. J Biol Chem 1999; 274: 34719-27.

17. Erb L, Garrad R, Wang $\mathrm{Y}$ et al. Site-directed mutagenesis of $\mathrm{P} 2_{\mathrm{U}}$ purinoceptors. Positively charged amino acids in transmembrane helices 6 and 7 affect agonist potency and specificity. J Biol Chem 1995; 270: 4185-8.

18. Qi A-D, Harden TK, Nicholas RA. GPR80/99, proposed to be the $\mathrm{P}_{2} \mathrm{Y}_{15}$ receptor activated by adenosine and AMP, is not a $\mathrm{P} 2 \mathrm{Y}$ receptor. Purinergic Signalling 2004; 1: 67-74 (this issue). 